\title{
Women's sexual and reproductive health care needs assessment: an Iranian perspective
}

Soghra Khani, ${ }^{1}$ Lida Moghaddam-Banaem, ${ }^{1}$ Eesa Mohamadi, ${ }^{2}$ Abu Ali Vedadhir ${ }^{3}$ and Ebrahim Hajizadeh 4

${ }^{1}$ Department of Midwifery and Reproductive Health; ${ }^{2}$ Department of Nursing; ${ }^{4}$ Department of Statistics, Faculty of Medical Sciences, Tarbiat Modares University, Tehran, Islamic Republic of Iran (Correspondence to: Lida Moghaddam-Banaem: moghaddamb@modares.ac.ir). ${ }^{3}$ Department of Anthropology, Faculty of Social Sciences, University of Tehran, Tehran, Islamic Republic of Iran.

\begin{abstract}
Background: Reproductive health problems are a leading cause of women's ill health and mortality worldwide. There is a need to investigate sexual and reproductive health care needs in different societies and cultural contexts. Despite the success in health care promotion in the Iranian health care system, women still need to receive sexual health care and appropriate HIV/AIDS services. However, studies on the sexual and reproductive health care needs of Iranian women are lacking.
\end{abstract}

Aims: This study aimed to investigate the sexual and reproductive health care needs of women referred to health care centres in an urban area of the Islamic Republic of Iran.

Methods: We carried out a cross-sectional study in 2013 on 514 women living in an urban area in the north of the Islamic Republic of Iran. Taking into consideration ethical principles, data were collected using the Sexual and Reproductive Health Care Needs Assessment Questionnaire.

Results: The findings showed a greater need for the provision of care by practitioners in the sexual history and activities domain (73\%) compared with other domains. Also, the woman's age and the location where she sought treatment and care for sexually transmitted infections were predictors of sexual activities needs.

Conclusions: Owing to the high prevalence of women's referral to health care centres seeking treatment of sexual disorders, there is a need for the provision of sexual counseling centres and services promoting women's reproductive health care.

Keywords: Iran, reproductive health, sexual health, needs assessment

Citation: Khani S; Moghaddam-Banaem L; Mohamadi E; Vedadhir AA; Hajizadeh E. Women's sexual and reproductive health care needs assessment: an Iranian perspective. East Mediterr Health J. 2018;24(7):637-643. https://doi.org/10.26719/2018.24.7.637

Received: 08/11/15; accepted: 28/05/17

Copyright (C) World Health Organization (WHO) 2018. Some rights reserved. This work is available under the CC BY-NC-SA 3.o IGO license (https:// creativecommons.org/licenses/by-nc-sa/3.o/igo).

\section{Introduction}

According to article 25 of the Universal Declaration of Human Rights (1948), health is considered a right of humans (1). All people have the right to have access to adequate information and services regarding sexual and reproductive health (SRH) care (2). The provision of SRH care for all has been repeatedly identified as a requirement to achieve the Millennium Development Goals (3). Improving SRH in society contributes to a reduction in poverty and the achievement of other development goals (4). Sexual and reproductive health comprises a wide variety of dimensions such as safe motherhood, family planning, HIV/AIDS and other sexually transmitted infections (STIs) as well as domestic violence (5). If there is any problem in providing or receiving health care services in each of the above-mentioned dimensions, women's SRH needs will be endangered (6).

Access to reproductive health care services influences global welfare and security through the acceleration of demographic transition and the shift from short life expectancy and large families to long life expectancy and small families (1). In 2010, 287000 women worldwide died owing to complications of pregnancy (7). It's worth noting that from 1990 to 2015 , less than $50 \%$ of deliveries in low-income countries were attended by a skilled health care provider (8). Also, $12 \%$ of women aged $15-49$ years who were married or in a sexual relationship wanted to avoid pregnancy, but had no access to, or could not use, effective contraception methods (9). Only about $56 \%$ of pregnant women received the recommended minimum 4 sessions of antenatal care (10). According to international law, SRH is a human right and plays an important role in morbidity, mortality and life expectancy, however, reproductive health problems are a leading cause of women's ill health and mortality worldwide (11), therefore, it is necessary to meet women's SRH care needs.

Despite the impressive success in health care promotion in the Iranian health care system, Iranian women are still in need of receiving sexual health care and appropriate HIV/AIDS services (12).

The main aspects of SRH, including gender, sexuality, reproduction and sexual relationships, should be investigated. given the cultural diversity in human societies (13). There is a lack of studies on the SRH needs of Iranian women; existing studies are limited to a few surveys conducted in specific or convenience groups such 
as adolescents (14), students (15), HIV-positive patients (16) and couples (17).

To the best of our knowledge, there are no studies regarding SRH needs assessment of women referred to health care centres in the Islamic Republic of Iran. Therefore, the aim of this study was to investigate the sexual and reproductive health care needs of women referred to health care centres in an urban area of the Islamic Republic of Iran. Our findings will help health care professionals understand women's health care needs and devise strategies for meeting these needs.

\section{Methods}

This cross-sectional study was conducted from February to July 2013. The sample included 514 women referred to health care centres in an urban area located in the north of the Islamic Republic of Iran. The following inclusion criteria were used: being a native Iranian, speaking Farsi and being in the reproductive age (15-49 years). Before the initiation of this study, an associate midwife provided the participants with all necessary information about their rights, the study method and data collection. Those who agreed to participate were asked to sign an informed consent form. In cases where the participant was illiterate, verbal informed consent was obtained. The study research proposal was approved by the ethics committee affiliated with Tarbiat Modares University.

To determine the sample size, a pilot study was conducted in which a sample of 50 women referred to health care centres in the study zone were asked to complete a questionnaire. It was found that $70 \%$ ( $P$ $=0.7$ ) of the samples declared the need for SHR care. Accordingly, the sample size was calculated using the following formula:

$$
\begin{gathered}
\mathrm{n}=[\mathrm{Z} 21-\alpha / 2 \times \mathrm{p}(1-\mathrm{p})] / \mathrm{d} 2 \\
\mathrm{n}=[(1.96) 2 \times(0.70 \times 0.30)] /(0.04) 2=504
\end{gathered}
$$

Taking into consideration possible losses, the number of participants was determined as 514. A multistage sampling method was used. A list of 20 health care centres was provided from three municipality districts in Sari, in the north of the country. Next, 12 centres were randomly selected using a random numbers table, four from each district. The number of women referred to each health care centre was identified. Taking into account the estimated sample size, 514 women were selected using the random numbers table. After obtaining written informed consent, those who met the inclusion criteria were interviewed by the centre midwife staff who were trusted by the participants.

To gather the data, the Sexual and Reproductive Health (SRH) Needs Assessment Questionnaire was used (18). This special tool, devised by the UNFPA, was selected because it covers the needs in various domains of reproductive health. The self-administered questionnaire comprised 114 items in seven domains: background data, safe motherhood morbidity profile and hygiene practices, family planning, sexual history and activities, STIs, HIV/ AIDS, and sexual- and gender-based violence. The Farsi version of the questionnaire was validated previously by Iranian researchers (19).

To choose the most common SRH needs, 2 panels of experts comprising the research team members, a health education specialist and a reproductive health specialist were invited to discuss women's needs in each domain and in total by assigning a score of 1 or 2 to each item. For instance, if a woman had inappropriate health care, she was considered to have a need for care and was given a score of 2 , and if the woman had ideal health care status, a score of 1 was given. Where an item had multiple options, it was decided that if the woman chose $>2$ options, a score of 2 was given and if the woman selected $\leq 2$ options, a score of 1 was allocated. Therefore, according to the scores, a dichotomous option was created: "having the need" and "having no need" (20). The sum of the scores for each domain was computed. The 5oth percentiles (cutoff point) of the sum of the scores were calculated and women who scored more than the cut-off points were recognized as having a need. Lastly, the frequency of the women's responses for each domain was calculated.

Regarding an item in the Iranian version of the questionnaire, it should be noted that in Iranian society, temporary marriage is defined and approved according to Article 1075, 1936, of the Iranian civil law. In the case of divorce or expiration of the marriage contract, the woman is allowed to marry again after three menstrual periods to ensure she is not pregnant by the previous partner.

We used SPSS, version 21, to analyse data. Frequency measures, independent sample t-test, chi-squared and logistic regression were the main statistical tests used for data analysis. $P$-values $<0.05$ were considered statistically significant.

\section{Results}

\section{Demographic characteristics}

The mean age of the participants was 31.6 [standard deviation $(S D)=7$ ] years. The mean age at marriage of the women and their husbands was $19.8(S D=5)$ years and $34.8(\mathrm{SD}=8)$ years, respectively. The education level of $41.7 \%$ of the women and $39.9 \%$ of their husbands was secondary high school and diploma, respectively. More details regarding demographic characteristics are provided in Table 1.

\section{Sexual and reproductive health needs}

According to the scores given to the women, the majority were recognized as having needs in all SRH domains (Table 2). Women's needs in the sexual history and activities domain (375 women, 73\%) were greater than in other SRH domains.

Seventy-two women (14.3\%) began their sexual activities before age 18 years (Table 3). Additionally, 13 women $(2.6 \%)$ had the experience of temporary marriage with more than 1 sexual partner in a year, and the majority (11 women) did not consistently use condoms in their sexual relationships. Nine women (1.8\%) suspected their husbands were having a sexual relationship with others. 


\begin{tabular}{lcc}
\hline $\begin{array}{l}\text { Table 1 Sociodemographic characteristics of participants } \\
\text { (n = 514) }\end{array}$ & \multicolumn{2}{c}{ Value } \\
\hline Characteristic & Mean & SD \\
\hline Age (years) & 31.6 & 7.5 \\
$\quad$ Age at marriage (years) & 20.9 & 4.0 \\
Husband's age (years) & 34.8 & 8.0 \\
\hline & No. & $\%$ \\
\hline Education level & & \\
\hline Below high school & 124 & 24.3 \\
High school diploma & 213 & 41.7 \\
$\quad$ Academic degree & 174 & 34.1 \\
\hline Education level of the husband & & \\
\hline Below high school & 140 & 28.4 \\
High school diploma & 205 & 41.6 \\
Academic degree & 148 & 30.0 \\
\hline Family breadwinner & & \\
\hline Participant & 14 & 2.8 \\
Husband & 461 & 91.5 \\
Other & 29 & 5.8 \\
\hline
\end{tabular}

$S D=$ standard deviation.

The t-test and chi-squared tests showed that age $(P=0.03)$, place where STI treatment was sought $(P=$ $0.001)$, current pregnancy $(P=0.005)$, history of unwanted pregnancy $(P=0.002)$, and history of sexual coercion $(P=$ 0.005 ) were associated with women's need in the sexual activities' domain. The variables with $0.05<P<0.2$ were history of beating $(P=0.1)$, marriage age $(P=0.1)$, education level $(P=0.1)$ and employment status $(P=0.1)$. All these variables $(P<0.2)$ were entered in the logistic

\begin{tabular}{|c|c|c|}
\hline Variable & No. & $\%$ \\
\hline \multicolumn{3}{|c|}{$\begin{array}{l}\text { Age of starting sexual } \\
\text { relationship (years) }\end{array}$} \\
\hline$<18$ & 72 & 14.3 \\
\hline$\geq 18$ & 442 & 85.7 \\
\hline \multicolumn{3}{|c|}{$\begin{array}{l}\text { Suspicion of husband sexual } \\
\text { relationship with others }\end{array}$} \\
\hline No & 439 & 85.4 \\
\hline Yes & 9 & 1.8 \\
\hline Don't know & 66 & 12.8 \\
\hline \multicolumn{3}{|c|}{ Temporary marriage } \\
\hline No & 489 & 95.2 \\
\hline Yes & 13 & 2.5 \\
\hline Missing & 12 & 2.3 \\
\hline \multicolumn{3}{|c|}{$\begin{array}{l}\text { Continuous use of condoms } \\
(n=13)\end{array}$} \\
\hline No & 11 & 78.6 \\
\hline Yes & 2 & 21.4 \\
\hline
\end{tabular}

Table 2 Distribution of women with sexual and reproductive health needs in six domains $(n=514)$

\begin{tabular}{lcccc} 
Domain & \multicolumn{2}{c}{$\begin{array}{c}\text { More } \\
\text { than 50th } \\
\text { percentile }\end{array}$} & \multicolumn{2}{c}{$\begin{array}{c}\text { Less } \\
\text { than 5oth } \\
\text { percentile }\end{array}$} \\
& No. & $\%$ & No. & $\%$ \\
\hline Safe motherhood & 268 & 52.1 & 246 & 47.9 \\
Family planning & 310 & 60.3 & 59 & 68.6 \\
Sexual history and activities & 375 & 73.0 & 139 & 27.0 \\
Sexually transmitted infections & 282 & 54.9 & 232 & 45.1 \\
HIV/AIDs & 274 & 53.3 & 240 & 46.7 \\
Violence & 263 & 51.2 & 251 & 48.8 \\
Total & 254 & 49.4 & 260 & 50.6 \\
\hline
\end{tabular}

regression analysis. Factors related to the women's sexual activities needs were: age $(P=0.002)$, place where STI treatment was sought $(P=0.014)$ and sexual coercion $(P$ $=0.003)$ (Table 4$)$.

\section{Discussion}

The majority of the participants asserted a need for SRH care in all domains. The women's needs in the domain of sexual history and activities were greater than in other domains. In a study in Sari, the most common SRH need of women who were referred to the health care centres was caesarean surgery (21). According to that study, the definition of the most common SRH need was based on the frequency of the item regardless of SRH domain. However, in our study we defined SRH needs based on the score given by the women and the 5oth percentile of the dichotomous need items in each domain. The high prevalence for women's needs in the sexual activities domain indicated that the women were comfortable in expressing their sexual needs. Another reason was that women sought equality with men, especially in terms of sexual rights (22).

Age, education level and marriage age had a significant statistical relationship with the women's sexual activities needs. According to a report to the Sixty-Fifth World Health Assembly, the latest international estimates indicated that more than 60 million women aged 20-24 years worldwide were married before age 18 years (23). Older age and higher education level are the protective factors for marriage and pregnancy in early adolescence (24). Although the prevalence of having

Table 4 The factors influencing the women's needs in the sexual history and activities domain $(n=514)$ )

\begin{tabular}{lccc} 
Factor & OR & $\mathbf{9 5 \%}$ CI & P-value \\
Age & 1.21 & $1.4-1.07$ & 0.002 \\
$\begin{array}{l}\text { Location where STI } \\
\text { treatment was sought }\end{array}$ & 2.50 & $1.7-8.11$ & 0.014 \\
Sexual coercion & 3.50 & $1.05-11.8$ & 0.03 \\
\hline
\end{tabular}

$\mathrm{OR}=$ odds ratio; $\mathrm{CI}=$ confidence interval; $\mathrm{STI}=$ sexually transmitted infection . 
multiple sexual partners was very low [ 13 women (2.6\%) experienced temporary marriage], the majority did not consistently use condoms in their sexual relationships. This behaviour influences the prevalence of STIs and may increase the prevalence of HIV/AIDS. Many of these women stated that their husbands preferred not to use condoms. In a study in South Africa, it was demonstrated that practical issues, such as financial constraints, were barriers to condom use (25); sex workers avoided condom use due to negative symbolism. Thus, the more they were exposed to risk of STIs and AIDS, the less they used condoms. A recent systematic review found a high prevalence of HIV among female sex workers (26). Fritz et al. showed that interventions focused on men and couples were necessary along with incentives to encourage men to participate in STI prevention programmes (27). Expanding condom use promotion programmes among couples may be an effective strategy for couples wishing to practice contraception (28).

Our results indicate there is a relationship between a woman's age and sexual activities needs domains. With older age, the need for sexual activities is lower. In a Canadian study, $34.4 \%$ of Inuit people used condoms in their sexual relationships, and this was more common in younger people (15-19 years) compared with those aged $\geq 30$ years $(29)$. There is a considerable diversity in the results of different studies, because sexual behaviours vary with age, marital or cohabiting status, education and ethnicity (30).

In our study, 134 women $(26 \%)$ experienced sexual coercion and $94.8 \%$ of perpetrators were their husbands/ partners. The reported prevalence is lower than the prevalence of sexual violence, partner or non-partner, in the Eastern Mediterranean Region (36.4\%) and globally (35\%) (31). The relatively high prevalence of this type of violence could be due to the cultural differences in various communities, so between 0.3 and $11.5 \%$ of women experience sexual violence by a non-partner after age 15 years (32).

Although, it seems that our definition of SRH needs (above the 5oth percentile) is likely to overestimate needs, the results are sufficient to illustrate that women referred to the health care centres do not have much access to appropriate SRH services. Our instrument was too lengthy to assess the women's SRH needs. Therefore, the researchers tried to incorporate the interviewer method, establish and promote a friendly atmosphere during the interviews, and provide a break with some refreshments in the middle of the sessions to prevent the participants from getting tired.

The research-based findings can assist policymakers and health care managers of SRH programmes in distributing the required resources and providing facilities and planning for educational and counselling programmes based on the most common SRH needs of women. Further studies are suggested to assess each domain of SRH needs separately. Although men are usually ignored in SRH research, their role is critical in women's general and sexual health. Thus, future studies need to assess the SRH needs of men.

One of the main limitations of this study was its descriptive design so that the relationships between the variables could not represent the causal relationships. Using logistic regression, the effects of confounder variables on the outcome variables were minimized. The sensitivity of some questions and an increased risk of nonresponse or false response by the women could be considered a limitation of this study. In this respect, we assured the women of the confidentiality of the collected data. In addition, before asking the participants to answer sensitive questions, to break the ice, they were asked some introductory questions, e.g. before asking about number of sexual partners (temporary marriage) in a year, they were asked, "Do women or girls with more than one temporary marriage in a year live in your neighbourhood?"

\section{Acknowledgements}

We would like to thank Dr Victoria James and the NEDICO team who kindly allowed us to translate and use the SRH questionnaire.

Funding: This study was part of the first author's $\mathrm{PhD}$ research project in reproductive health, supported financially by the Faculty of Medical Sciences, Tarbiat Modares University, Tehran.

Competing interests: None declared. 


\section{Évaluation des besoins des femmes en matière de soins de santé sexuelle et génésique : perspective iranienne}

\section{Résumé}

Contexte : Les problèmes de santé génésique comptent parmi les principales causes de mauvaise santé et de mortalité féminine dans le monde. Une évaluation des besoins en matière de soins de santé sexuelle et génésique doit être effectuée dans différentes sociétés et divers contextes culturels. Malgré les succès obtenus dans la promotion des soins de santé au sein du système de santé iranien, les femmes ont encore besoin de bénéficier de soins de santé sexuelle et de traitement $\mathrm{du} \mathrm{VIH} /$ sida appropriés. Cependant, les études portant sur les besoins des femmes iraniennes en matière de soins de santé sexuelle et génésique sont insuffisantes.

Objectif : La présente étude avait pour objet d'examiner les besoins en soins de santé sexuelle et génésique chez des femmes ayant été orientées vers des centres de soins dans une zone urbaine de République islamique d'Iran.

Méthodes : En 2013, nous avons réalisé une étude transversale portant sur 514 femmes demeurant dans une zone urbaine située dans le nord de la République islamique d'Iran. Les données ont été recueillies dans le respect des principes éthiques et à l'aide du Questionnaire d'évaluation des besoins en soins de santé sexuelle et génésique.

Résultats : Les résultats ont démontré que les médecins devaient prodiguer davantage de soins et de conseils dans le domaine des antécédents sexuels et des activités sexuelles ( 73 \%) que dans d'autres domaines. En outre, lâge de la femme et le lieu où elle avait demandé à recevoir un traitement et des soins suite à une infection sexuellement transmissible constituaient des facteurs prédictifs des besoins de traitement associés aux activités sexuelles.

Conclusion : La forte prévalence de femmes dirigées vers des centres de soins en vue d'obtenir des traitements contre des affections sexuelles indique la nécessité de mettre en place des centres et des services de conseil en santé sexuelle pour promouvoir les soins de santé génésique de la femme.

$$
\begin{aligned}
& \text { تقييم احتياجات رعاية الصحة الجنسية والإنجابية للمر أث: وجهة نظر من جمهورية إيران الإسلامية }
\end{aligned}
$$

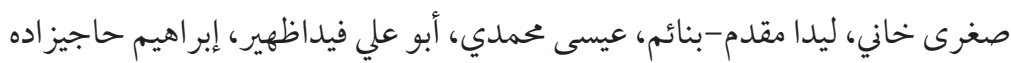

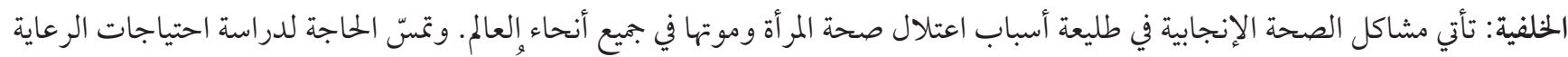

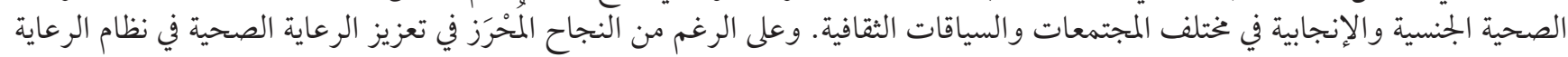

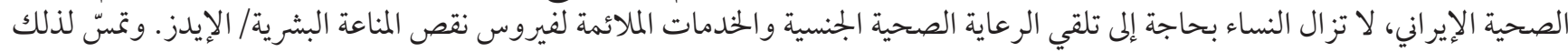

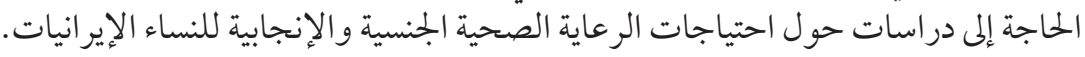

الأهداف: دراسة احتياجات الرعاية الصحية الجنسية والإنجابية للنساء المحالات إلى مراكز الرعاية الصحية في منطقة حضرية في جمهورية إيران الإسلامية.

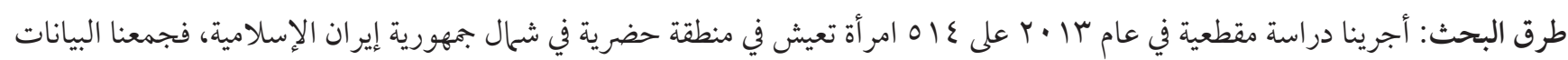

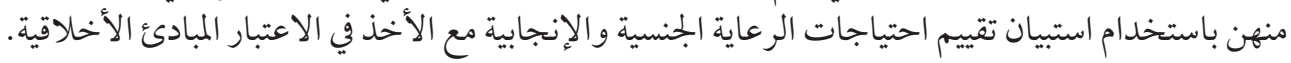

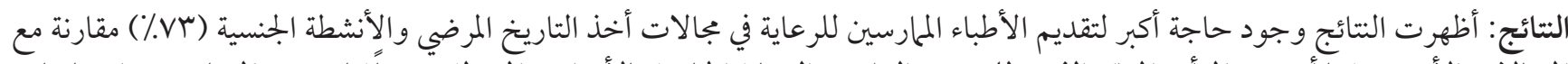

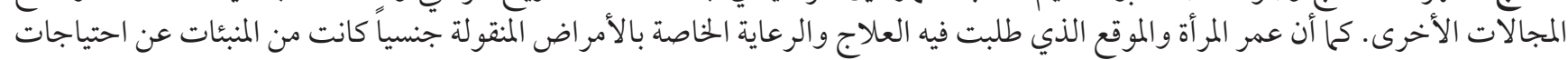
الأنشطة الجنسية.

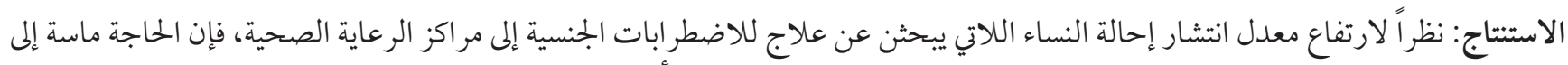

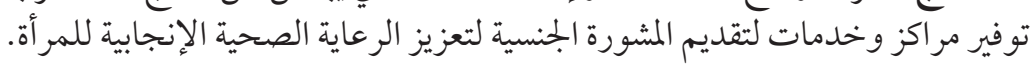

\section{References}

1. Universal declaration of human rights. NewYork: United Nations; 2013 (http://www.un.org/en/universal-declaration-human-rights/index.html, accessed 25 February 2018).

2. United Nations Population Information Network (POPIN). Guidelines on reproductive health New York: UnitedNations; 2012 (http://www.un.org/popin/unfpa/taskforce/guide/iatfreph.gdl.html, accessed 25 February 2018).

3. Crossette B. Reproductive health and the Millennium Development Goals: the missing link. Studies in Family Planning. 2005;36:71-9. doi:10.1111/j.1728-4465.2005.00042.x.

4. Bernstein S, Hansen CJ. Public choices, private decisions: sexual and reproductive health and the Millennium Development Goals. New York: UNDP, 2006.

5. Williams K, Warren C, Askew I. Planning and implementing, an essential package of sexual and reproductive health services 
guidance for integrating family planning and STI/RTI with other reproductive health and primary health services. NewYork: UNFPA, Population Council; 2010.

6. Glasier A, Gülmezoglu AM, Schmid GP, Moreno CG, Van Look PF. Sexual and reproductive health: a matter of life and death. Lancet. 2006;368(9547):1595-607. https://doi.org/10.1016/So140-6736(06)69478-6 PMID:17084760

7. Say L, Chou D, Gemmill A, Tunçalp Ö, Moller A-B, Daniels J, et al. Global causes of maternal death: a WHO systematic analysis. The Lancet Global Health. 2014;2(6):e323-33. https://doi.org/10.1016/S2214-109X(14)70227-X PMID:25103301

8. Trends in maternal mortality: 1990 to 2013, estimates by WHO, UNICEF, UNFPA, the World Bank and the United Nations Population Division. Geneva: World Health Organization; 2014 (http://www.who.int/reproductivehealth/publications/monitoring/maternal-mortality-2013/en/, accessed 25 February 2018).

9. WHO. Maternal and reproductive health. Geneva: World Health Organization; 2010 http://www.who.int/gho/maternal_health/ en/, accessed 25 February 2018).

10. WHO. Universal access to reproductive health. Geneva: World Health Organization; 2013

11. Fathalla M, Sinding S, Rosenfield A, Fathalla M. Sexual and reproductive health for all: a call for action. Lancet. 2006 Dec 9;368(9552):2095-100. https://doi.org/10.1016/So140-6736(06)69483-X PMID:17161731

12. Asaei S. Iran's excellent primary health care system. Tehran: UNICEF Iran; 2014 (http://www.unicef.org/iran/media_4427.html, accessed 25 February 2018).

13. Weber L. A conceptual framework for understanding race, class, gender, and sexuality. Psychol Women Quarterly. 1998;22:13-32. DOI: 10.1111/j.1471-6402.1998.tboo139.x

14. Olfati F, Aligholi S. A study on educational needs of teenagaer girls regarding the reproductive health and determination of paper strategies in achieving the target goals in Qazvin. J Qazvin Univ Med Sci. 2008;12(2):76-82.

15. Naghibi M, Sharif MN, Ramzani Z, Hashemian M, Tabarraie Y. Comparison of educational needs of girls and boys students of Medical Science of Sabzevar about some reproductive health components. 11th Conference of Science and Health of Shahrud University of Healthcare and Educational Sciences, 2011; Shahrud, Iran.

16. Hajizadeh S, Nejat S, Majdzadeh SR, Setayesh HR, Guya MM. Fertility intentions of patients who reffered to behavioral clinics of universities of medical sciences in Tehran. J Isfahan Med Sch. 2011;29(167):1-10.

17. Aghdak P, Majlesi F, Zeraati H, EftekharArdebili H. Reproductive related needs in marriage volounteers. Payesh. 2009;8 (4):37985 .

18. Sexual and reproductive health (SRH) needs assessment among mobile and vulnerable population (MPV) communities in Zimbabwe. Study report. Harare, Zimbabwe: NEDICO \& UNFPA; 2008.

19. Khani S, Moghaddam-Banaem L, Mohamadi E, Vedadhir A, Hajizadeh E. Psychometric properties of the Persian version of the Sexual and Reproductive Health Needs Assessment Questionnaire. East Mediterr Health J. 2015;21(1):29-38. PMID:25907190

20. Walker SC, Kerns SE, Lyon AR, Bruns EJ, Cosgrove T. Impact of school-based health center use on academic outcomes. J Adolesc Health. 2010;46(3):251-7. https://doi.org/10.1016/j.jadohealth.2009.07.002 PMID:20159502

21. Khani S, Banaem LM, Mohammadi E, Vedadhir A, Hajizadeh E. The most common sexual and reproductive health needs in women referred to healthcare and triangle centers of Sari-2013. J Mazandaran Univ Med Sci. 2014;23(1):45-53.

22. McCarthy B, McCarthy E. Rekindling desire, 2nd ed. NewYork: Routledge; 2014.

23. Early marriages, adolescent and young pregnancies, report by the Secretariat. Sixty-fifth World Health Assembly, provisional agenda item 13.4. Geneva: World Health Organization; 2012 (A65/13).

24. Singh S, Darroch J. Adding it up: cost and benefits of contraceptive services-estimates for 2012. New York: Guttmacher Institute and United Nations Population Fund (UNFPA); 2012 (http://www.guttmacher.org/pubs/AIU-2012-estimates.pdf, accessed 25 February 2018).

25. Varga C. The condom conundrum: barriers to condom use among commercial sex workers in Durban, South Africa. African J Reprod Health. 1997;1(1):74-88. https://doi.org/10.2307/3583277 PMID:10214405

26. Baral S, Poteat T, Stromdahl S, Writz A, Guadamuz T, Beyrer C. worldwide burden of HIV in transgender women: a systematic review and meta-analysis. Lancet. 2013;13(March):214-22. https://doi.org/10.1016/S1473-3099(12)70315-8 PMID:23260128

27. Fritz K, McFarland W, Wyrod R, Chasakara C, Makumbe K, Chirowodza A, et al. Evaluation of a peer network-based sexual risk reduction intervention for men in beer halls in Zimbabwe: results from a randomized controlled trial. AIDS and Behavior. 2011;15(8):1732-44. https://doi.org/10.1007/s10461-011-9922-1 PMID:21380493

28. Haddad LB, Feldacker C, Jamieson DJ, Tweya H, Cwiak C, Chaweza T, et al. Pregnancy prevention and condom use practices among HIV-infected women on antiretroviral therapy seeking family planning in Lilongwe, Malawi. PloS One. 2015;10(3):e0121039. https://doi.org/10.1371/journal.pone.0121039 PMID:25811849

29. Dodin S, Blanchet C, Rochette L, Dupont M, Papineau É, Anctil M. Qanuippitaa?: How are we?: Women's health and preventive sexual behaviour among men and women. Régie régionale de la santé et des services sociaux: Nunavik, Quebec; 2007.

30. Khan A. Gender-based violence and HIV: a program guide for integrating gender-based violence prevention and response in PEFAR programs. Arlington, Virginia: USAID's AIDS Support and Technical Assistance Resources, AIDSTAR-One, Task Order 1; 2011:1-70. 
31. Global and regional estimates of violence against women: prevalence and health effects of intimate partner violence and non-partner sexual violence. Geneva: World Health Organization; 2013.

32. Garcia-Moreno C, Stockl H. Protection of sexual and reproductive health rights: addressing violence against women. Int J Gynaecol Obstet. 2009;106:144-7. https://doi.org/10.1016/j.ijgo.2009.03.053 PMID:19560770 